\title{
Whey Protein, but Not Soy Protein, Supplementation Alleviates Exercise- induced Lipid Peroxidation in Female Endurance Athletes
}

\author{
Myra K. Tara, Jean Soon Park, Bridget D. Mathison, Lindsey L. Kimble, and Boon P. Chew*
}

School of Food Science, Washington State University, Pullman, WA 99164-6376, WA, USA

\begin{abstract}
Purpose: The objective of this study was to assess the protective effects of whey and soy protein supplementation on inflammatory response, oxidative damage and body composition in active female endurance athletes.

Methods: Healthy female endurance athletes $(18-25 \mathrm{y} ; n=18)$ running at least one hour per day, five days per week were randomly assigned to consume $40 \mathrm{~g}$ whey or soy protein daily, in a 6-wk double-blind study. Blood samples were obtained following completion of a one hour run at baseline and wk 6, and analyzed for inflammatory and oxidative biomarkers. DXA scans were completed to determine body composition.

Results: Whey protein intervention decreased $(P<0.05)$ plasma TBARS concentrations, indicating suppressed lipid peroxidation. Supplementation with soy protein had no effect on markers of oxidative damage and inflammation, but decreased $(P<0.05)$ reduced glutathione indicating a reduction in antioxidant activity. Protein supplementation had no significant effect on body composition.

Conclusions: Supplementation with whey protein decreased lipid peroxidation in in female endurance athletes suggesting a potential antioxidative action, while soy protein did not improve biomarkers of oxidative damage and inflammation.
\end{abstract}

Keywords: Inflammation, endurance exercise, body composition, protein supplementation.

\section{INTRODUCTION}

Many athletes consider nutritional supplements critical for supporting exercise performance and longevity [1] and it is estimated that $89 \%$ of college athletes have used or currently use nutritional supplements to enhance their performance [2]. The primary source of fuel during endurance exercise is muscle glycogen and depletion of intramuscular glycogen stores is shown to limit performance during prolonged exercise [3]. Recovery from endurance exercise is essential as muscle damage results in the breakdown of muscle protein and impairs muscle function, glycogen synthesis rates, and protein synthesis pathways [4]. Therefore, endurance athletes have increased energy and protein requirements to fuel exercise, replace glycogen stores, and support muscle protein synthesis $[5,6]$.

Undesirable metabolic changes occur during endurance exercise that can be detrimental to physiological homeostasis, including increased cytokine production, inflammation, and oxidative damage [7]. Increased aerobic metabolism creates a high oxygen demand for increased ATP production to provide energy, resulting in the production of reactive oxygen species (ROS) and other metabolic byproducts [7]. While ROS are natural byproducts of cellular respiration and are essential for cell signaling and homeostasis, the ensuing cascade from these free radicals can result in cellular

\footnotetext{
"Address correspondence to this author at the School of Food Science, FSHN 110, Washington State University, Pullman, WA 99164-6376, USA; Tel: 509-335-1427; Fax: 509-335-4815; E-mail: boonchew@wsu.edu
}

damage, including apoptosis, protein oxidation, DNA modification, and lipid peroxidation [8]. Under normal conditions ROS are tightly controlled by endogenous antioxidant systems; however, endurance athletes place a high demand on these systems, which can become overwhelmed by ROS resulting in excessive ROS accumulation and oxidative stress [9]. Further, inflammation and oxidative stress are linked to muscle damage and increased recovery time in endurance athletes [7].

Body composition may also play a role in overall athletic performance. Body weight can influence an athlete's speed, endurance and power, leading some athletes to restrict calories in order to lose weight [1]. In weight-sensitive sports, athletes may use extreme methods to reduce mass rapidly or maintain a low body mass in order to gain a competitive advantage [10]. Body fat is a source of stored energy and is essential for maintaining body temperature, protecting vital organs, and reproductive health. In female endurance athletes specifically, unstable menstrual function resulting from restricted dietary intake and undesirably low body fat percentage may be related to decreases in bone mineral density (BMD) [11]. While genetic factors have been suggested to be the strongest determinants of maximal bone mass, nutrition and mechanical loading are also shown to play significant roles [12]. Similarly, iron deficiency affects approximately $16 \%$ of US females between $18-45$ years old; iron is a key component of heme-containing proteins that are essential for oxygen transport throughout the body [13]. Therefore, low iron levels may compromise athletic performance. 
Whey and soy protein are high-quality protein sources with antioxidant capacities; therefore, they may alleviate inflammation-associated oxidative damage and improve body composition. Whey protein consumption has been shown to alleviate endurance exercise-induced oxidative stress in mice, as whey protein contains cysteine which plays a role in the biosynthesis of the intracellular antioxidant glutathione [14]. Whey protein also plays a role in bone remodeling [15] and has been shown to increase lean body mass and muscle strength following resistance training [16]. Soy isoflavone intervention has been shown to inhibit DNA damage, which may protect against many chronic diseases [17]. Additionally, soy protein prevented exercise-induced protein degradation of skeletal muscle in rats following acute aerobic exercise [18]. Similarly, acute aerobic exercise combined with soy isoflavone supplementation increased lean body mass, restored bone mass and prevented body fat accumulations in ovariectomized mice [19].

In humans, milk protein consumption was shown to stimulate protein synthesis following resistance exercise in humans to a greater extent than soy protein supplementation [20]. While limited information is available on the effects of protein supplementation in endurance athletes; Hill et al. [4] found that co-ingestion of carbohydrate and whey protein had beneficial effects on recovery in male endurance athletes. Therefore, the objective of this study was to assess the protective effects of whey and soy protein supplementation on inflammatory response, oxidative damage and body composition in female endurance athletes.

\section{MATERIALS AND METHODOLOGY}

\section{Participants and Study Design}

Healthy female endurance athletes $(21.3 \pm 0.4$ y) were recruited from the Washington State University intercollegiate athletic program and the surrounding community between March and April 2007. Active endurance athlete status was defined as a minimum of one hour running per day, five days per week, during the previous year. Additional exclusion criteria included tobacco use, cancer, HIV, diabetes or other metabolic diseases. The Institutional Review Board of Washington State University approved all study procedures and all participants provided informed consent.

Initial body fat percentage of participants was used for assignment to treatment groups (mean \pm SEM: $23.1 \pm 1.9$ and $20.4 \pm 2.3$ for whey and soy, respectively) in a randomized double-blind experimental design. Participants were randomly assigned with computer-generated random numbers to receive either commercially available whey $(n=10)$ or soy $(n=8)$ isolate protein powders (Whey Protein Isolate: $89.3 \mathrm{~g}$ protein, $1.1 \mathrm{~g}$ fat, $3.6 \mathrm{~g}$ carbohydrates per $100 \mathrm{~g}$; Soy Protein Isolate: $83.3 \mathrm{~g}$ protein, $4.2 \mathrm{~g}$ fat, $<2.1 \mathrm{~g}$ carbohydrates, $175 \mathrm{mg}$ isoflavones per $100 \mathrm{~g}$; NOW Foods, Surfside, FL) daily for $6 \mathrm{wk}$. Each serving was standardized to $40 \mathrm{~g}$ protein that was consumed daily as a drink. Participants were instructed to consume one serving daily and that the beverage could be consumed in one dose or spread out over the course of the day. Consumption of dietary antioxidant and protein supplements, as well as foods high in soy, during the study was discouraged. Participants were instructed to maintain their normal exercise routines throughout the study, with a minimum requirement of one hour running per day, five days per week. A certified athletic trainer monitored the participants' health condition and exercise intensity. Compliance was assessed via personal communication, exercise logs and supplement records. Additionally, subjects completed a three-day dietary record including two weekdays and one weekend day. Dietary data was analyzed using The Food Processor for Windows Version 8.5 (ESHA Research, Salem, OR).

Blood and urine samples were obtained at baseline (wk 0 ) and after whey and soy dietary intervention (wk 6) at the Washington State University Athletic Training Facility (Pullman, WA). Blood was collected into heparinized evacuated tubes within one hour of completion of a one hour run. An aliquot of whole blood from each subject was used for glutathione analysis. The remainder was centrifuged $(400 \times$ $\mathrm{g}, 30 \mathrm{~min}, 4^{\circ} \mathrm{C}$ ) and plasma aliquoted and frozen at $-80^{\circ} \mathrm{C}$ until analysis (Bioactives Research Lab, Washington State University, Pullman, WA).

\section{Oxidative Damage}

Lipid peroxidation in plasma was analyzed by measuring thiobarbituric acid reactive substances (TBARS), as previously described [21] with modifications. Plasma samples $(500 \mu \mathrm{L})$ were reacted with $3 \mathrm{~mL} 1 \%$ phosphoric acid, $1 \mathrm{~mL}$ $0.6 \%$ thiobarbituric acid solution and $50 \mu \mathrm{LKCl}$. The mixture was heated in a $90^{\circ} \mathrm{C}$ water bath for $45 \mathrm{~min}$, cooled on ice and $4 \mathrm{~mL}$ n-butanol added. The butanol phase was separated by centrifugation $\left(10 \mathrm{~min}\right.$ at $\left.400 \times \mathrm{g}, 20^{\circ} \mathrm{C}\right)$, and optical density read at $532 \mathrm{~nm}$ and $520 \mathrm{~nm}$ (Beckman DU 640B, Seattle, WA). A standard curve was generated with tetramethoxypropane, and the assay detection limit was $0.381 \mu$ molmalonyldialdehyde/L. Oxidative damage to DNA was assessed in plasma by measuring 8-hydroxy-2'deoxyguanosine (8-OHdG; Bioxytech 8-OHdG-EIA kit, OXIS Health Products, Portland, OR). The lower limit of detection for $8-\mathrm{OHdG}$ was $0.5 \mathrm{ng} / \mathrm{mL}$.Plasma protein carbonyl, an indicator of protein oxidation, was measured using a colorimetric assay (Protein Carbonyl Assay kit, Cayman Chemical, Ann Arbor, MI) based on the reaction of 2,4dinitrophenylhydrazine (DNPH) with the protein carbonyls. The protein-hydrazone produced is quantitated at $\mathrm{OD}_{370}$ and concentration calculated using the extinction coefficient of DNPH.

\section{Inflammatory Biomarkers}

Plasma C-reactive protein (CRP), an indicator of inflammatory processes, was analyzed with a sandwich ELISA (Human CRP ELISA kit, Alpha Diagnostic International, San Antonio, TX). The lower limit of detection was 0.35 $\mathrm{ng} / \mathrm{mL}$. Plasma IL-1 $\alpha$, IL-1 $\beta$, IL-2, IL-6, IL-8, TNF- $\alpha$ and interferon (IFN)- $\gamma$ were analyzed using a multiplex format ELISA (Q-Plex Human Cytokine Array, Quansys, Logan, UT). Lower limits of detection were 4.10, 1.10, 1.36, 1.36, 2.11, and $\leq 1.0 \mathrm{ng} / \mathrm{L}$ for IL-1 $\alpha$, IL-1 $\beta$, IL-2, IL- 8 , TNF- $\alpha$ and IFN- $\gamma$, respectively. Digital images (Canon EOS 40D, Canon, Irvine, CA) were acquired using imaging capture software (Digital Imaging Professional 3.3, Canon, Irvine, CA, USA). Data obtained were analyzed using Quansys QView 2.5.5 software. 


\section{Antioxidant Activity}

Total antioxidant capacity, including hydrophilic and lipid-soluble antioxidants, was measured in plasma using a colorimetric assay (Antioxidant Assay kit, Cayman Chemical, Ann Arbor, MI). Assay sensitivity was 0.044 mmolTrolox equivalents/L. Reduced glutathione (GSH) and oxidized glutathione (GSSG) were measured in whole blood (Bioxytech GSH/GSSG-412 kit, OXIS Health Products, Portland, OR). To prevent oxidation of GSHto GSSG, 1-methyl-2-vinylpyridium trifluoromethanesulfonate was added to whole blood aliquots immediately following collection. Lower limits of detection were $0.54 \mu \mathrm{mol} / \mathrm{L}$ and $0.54 \mu \mathrm{mol} / \mathrm{L}$ for GSH and GSSG, respectively.

\section{Iron Analysis}

Post-intervention (wk 6) serum samples were analyzed for iron, total iron binding capacity (TIBC), unsaturated iron binding capacity (UIBC) and \% transferrin saturation (\%Sat) (Pathologists Regional Laboratories, Moscow, ID).

\section{Body Composition}

Dual x-ray energy absorptiometry (DXA) scans were performed by a registered radiographic technologist (Palouse Medical Center, Pullman, WA) at wk 0 and 6.

\section{Statistical Analysis}

Data were analyzed using the GLM procedure of SAS (version 8; SAS Institute). Differences between wk within treatment were analyzed by ANOVA. The final statistical model included treatment, week, BMI and exercise status. Differences in treatment means were compared using protected least significant differences and were considered significant at $P<0.05$.

\section{RESULTS}

\section{Subjects}

BMI was not different between treatment groups (mean \pm SEM: $22.1 \pm 0.7$ and $20.5 \pm 0.5$ for whey and soy, respectively). There were no differences in protein, carbohydrate, fat or energy intake between treatment groups. Overall mean daily intakes for participants from both groups were $100 \pm 7$ g protein, $331 \pm 28 \mathrm{~g}$ carbohydrate, $90 \pm 9 \mathrm{~g}$ fat and $2511 \pm$ $181 \mathrm{kcal}$. Protein accounted for in treatment supplementation was not included in the dietary intake analysis. The average exercise time for all participants was $345 \pm 40 \mathrm{~min} / \mathrm{wk}$; there was no significant difference in total activity between treatment groups.

\section{Oxidative Damage}

Whey protein supplementation decreased $(P<0.05)$ TBARS at wk 6 when compared to wk 0 , while soy protein supplementation had no effect on TBARS over the period studied (Table 1). Plasma 8-OHdG concentrations were not different within the treatment groups over the period studied (Table 1). Protein carbonyl concentrations were not different at baseline or wk 6 (Table 1).

\section{Inflammatory Biomarkers}

Plasma concentrations of CRP were not different between whey and soy treatments at baseline (Table 1). Soy protein supplementation had no effect on plasma CRP, while whey protein supplementation tended to decrease CRPat wk 6 when compared to the corresponding baseline concentration. Concentrations of all cytokines measured were not different between groups at baseline (overall means: $22.7 \pm 5.3$, $59.5 \pm 5.0,51.3 \pm 0.6,27.6 \pm 2.9,9.2 \pm 1.0,5.8 \pm 0.5$, and $7.8 \pm 2.1 \mathrm{pg} / \mathrm{mL}$ for IL-1 $\alpha$, IL-1 $\beta$, IL-2, IL-6, IL-8, TNF- $\alpha$, and IFN- $\gamma$, respectively). Whey protein supplementation

Table 1. Inflammatory and Oxidative Damage Biomarker Concentrations in Active Female Endurance Athletes Who Consumed Whey or Soy Protein for $6 \mathrm{wk}$, mean \pm SEM.

\begin{tabular}{|l|c|c|c|c|}
\hline \multirow{2}{*}{} & \multicolumn{2}{|c|}{ Whey } & \multicolumn{2}{c|}{ Soy } \\
\cline { 2 - 5 } & Wk 0 & Wk 6 & Wk 0 & Wk 6 \\
\hline \hline TBARS $(\mu \mathrm{mol} / \mathrm{L})$ & $1.7 \pm 0.2$ & $1.0 \pm 0.2^{*}$ & $21.7 \pm 6.0$ & $1.4 \pm 0.2$ \\
\hline 8 -OHdG $(\mu \mathrm{g} / \mathrm{mL})$ & $20.7 \pm 4.1$ & $21.2 \pm 3.6$ & $6.4 \pm 0.6$ & $17.5 \pm 4.2$ \\
\hline Protein carbonyl $(\mathrm{nmol} / \mathrm{L})$ & $7.0 \pm 0.6$ & $7.1 \pm 0.6$ & $1.7 \pm 0.3$ & $8.1 \pm 0.5$ \\
\hline CRP $(\mathrm{mg} / \mathrm{L})$ & $3.1 \pm 1.0$ & $2.4 \pm 0.6$ & $14.9 \pm 4.2$ & $1.8 \pm 0.4$ \\
\hline IL-1 $\alpha(\mathrm{pg} / \mathrm{mL})$ & $28.9 \pm 8.9$ & $23.1 \pm 6.6$ & $57.0 \pm 5.6$ & $13.0 \pm 6.7$ \\
\hline IL-1 $\beta(\mathrm{pg} / \mathrm{mL})$ & $61.5 \pm 7.9$ & $55.5 \pm 4.7$ & $1220 \pm 70$ & $58.9 \pm 6.7$ \\
\hline GSH $(\mu \mathrm{mol} / \mathrm{L})$ & $1152 \pm 67$ & $1004 \pm 33$ & $7.9 \pm 0.8$ & $1037 \pm 36^{*}$ \\
\hline GSSG $(\mu \mathrm{mol} / \mathrm{L})$ & $7.9 \pm 0.9$ & $6.6 \pm 0.8$ & $167 \pm 20$ & $7.2 \pm 0.7$ \\
\hline GSH:GSSG ratio & $156 \pm 17$ & $161 \pm 12$ & & $150 \pm 11$ \\
\hline
\end{tabular}

*Differences between wk within treatment were considered significant at $P<0.05$. 
tended to decrease plasma IL- $1 \alpha$ and IL-1 $\beta$ concentrations post-intervention as compared to baseline (Table 1), while supplementation with soy protein did not have a similar effect. Neither whey nor soy protein intervention had a significant effect on plasma IL-2, IL-6, IL-8, TNF- $\alpha$, or IFN- $\gamma$ at wk 6 (overall means: $51.1 \pm 0.5,34.3 \pm 3.6,7.4 \pm 1.1,5.4 \pm$ 1.7 , and $7.1 \pm 1.8 \mathrm{pg} / \mathrm{mL}$ for IL-2, IL-6, IL-8, TNF- $\alpha$, and IFN- $\gamma$, respectively).

\section{Antioxidant Activity}

GSH concentrations were not different between whey and soy protein groups at baseline (Table 1). Soy protein intervention decreased $(P<0.05)$ GSH concentrations at wk 6 as compared to wk 0 , while whey protein supplementation had no effect on GSH over the period studied. GSSG and GSH:GSSG ratio were not different over the time period studied (Table 1). Similarly, there was no difference in plasma total antioxidant capacity at baseline (overall mean: $1.6 \pm 0.2 \mathrm{mmol} / \mathrm{L}$ ) or wk 6 (overall mean: $1.4 \pm 0.1 \mathrm{mmol} / \mathrm{L}$ ).

\section{Iron Analysis}

Serum iron, TIBC, UIBC and \%Sat concentrations did not differ between treatment groups. In the whey group, means \pm SEM were $97.6 \pm 13.4 \mu \mathrm{g} / \mathrm{dL}, 231.1 \pm 21.2 \mu \mathrm{g} / \mathrm{dL}$, $328.7 \pm 17.3 \mu \mathrm{g} / \mathrm{dL}$, and $29.9 \pm 4.6 \%$ for serum iron, TIBC, UIBC and \%Sat, respectively. In the soy group, means \pm SEM were $71.1 \pm 14.0 \mu \mathrm{g} / \mathrm{dL}, 280.4 \pm 21.8 \mu \mathrm{g} / \mathrm{dL}, 351.5 \pm$ $17.3 \mu \mathrm{g} / \mathrm{dL}$, and $20.1 \pm 4.3 \%$, for serum iron, TIBC, UIBC and $\%$ Sat, respectively.

\section{Body Composition}

At baseline, total bone mineral content (BMC), BMD, body fat and lean mass were similar between treatment groups (Table 2). Whey and soy protein supplementation did not significantly affect total BMC, BMD, body fat and lean mass.

\section{DISCUSSION}

Metabolic changes during endurance exercise can be detrimental to physiological homeostasis, resulting in inflammation, oxidative stress and cellular damage. Elevated oxidative stress and inflammation related to prolonged periods of severe training may be associated with decline in athletic performance [22]. Therefore, recovery from endurance exercise is essential as muscle damage results in the breakdown of muscle protein and impairs muscle function, glycogen synthesis rates, and protein synthesis pathways [4]. The type of protein consumed can affect the recovery process due to differences in the digestion rate of the protein and concentration [23]. Overall, this study showed that whey protein supplementation plays a role in decreasing oxidative damage in active female endurance athletes, while soy protein did not improve biomarkers of oxidative stress and inflammation.

Prolonged periods of severe training have been shown to induce a marked response in oxidative stress biomarkers including increased urinary isoprostanes, TBARS, and protein carbonyls in humans [22]. In the current study, plasma TBARS concentrations decreased with whey protein intervention, indicating suppressed lipid peroxidation and a potential alleviation of exercise-induced oxidative stress. Similarly, whey protein administered with carbohydrate decreased plasma TBARS levels in human after cycling [24] and oral administration of whey protein was associated with decreased lipid peroxidation in rats [25]. Lipid peroxidation leads to the generation of byproducts involved in the activation of inflammatory response and cellular damage, therefore this protective effect of whey protein on oxidative stress may also help to reduce inflammation. In contrast, soy protein supplementation had no effect on plasma TBARS concentrations. Similarly, soy isoflavone supplementation had no effect on markers of lipid peroxidation in postmenopausal women [17]. Neither whey nor soy protein supplementation had an effect on plasma concentrations of 8-OHdG, which reflect oxidative damage to DNA as concentrations increase during DNA repair. While in vitro studies have shown that physiologic concentrations of soy isoflavones protect against DNA oxidative damage [26, 27], similar results were not seen in vivo in healthy men who consumed soy milk for 4 weeks [26]. However, postmenopausal women receiving soy isoflavones for 16 weeks had significantly lower plasma concentrations of 8-OHdG [17].

Athletes often develop a transient inflammatory response following intense acute exercise [22]. CRP is produced by the liver in response to inflammatory cytokines, such as IL-1 and IL-6, and elevated CRP levels are a reliable marker of inflammation [28]. Plasma concentrations of inflammatory cytokines are elevated in endurance athletes, likely indicating the presence of exercise-induced inflammation [29, 30]. The consumption of an experimental carbohydrate-whey protein cake was shown to decrease CRP and IL-6 levels after exhaustive cycling in humans [24], while other research examining the effects of soy intake on biomarkers of in-

Table 2. Body Composition of Active Female Endurance Athletes Who Consumed Whey or Soy Protein for 6 wk, mean \pm SEM. Differences between wk within treatment were considered significant at $P<0.05$.

\begin{tabular}{|l|c|c|c|c|}
\hline \multirow{2}{*}{} & \multicolumn{2}{|c|}{ Whey } & \multicolumn{2}{c|}{ Soy } \\
\cline { 2 - 5 } & Wk 0 & Wk 6 & Wk 0 & Wk 6 \\
\hline \hline Total BMC $(\mathrm{g})$ & $2181 \pm 129$ & $2214 \pm 120$ & $2181 \pm 113$ & $1.1 \pm 0.1$ \\
\hline Total BMD $\left(\mathrm{g} / \mathrm{cm}^{2}\right)$ & $1.1 \pm 0.1$ & $1.1 \pm 0.1$ & $10.8 \pm 1.4$ & $1.1 \pm 0.1$ \\
\hline Total fat $(\mathrm{kg})$ & $13.8 \pm 1.6$ & $13.6 \pm 1.7$ & $43.4 \pm 1.9$ & $43.9 \pm 1.9$ \\
\hline Total lean mass $(\mathrm{kg})$ & $43.7 \pm 1.6$ & $43.6 \pm 1.7$ & & 21.0 \\
\hline
\end{tabular}


flammation found no significant changes in CRP concentrations [17]. In the present study, whey and soy protein supplementation had no significant effect on the inflammatory biomarkers examined, however participants who consumed whey protein tended to have lower plasma IL- $1 \alpha$, IL-1 $\beta$, and CRP concentrations after $6 \mathrm{wk}$ of supplementation.

The prevention of oxidative damage and inflammation is likely mediated by the quenching of ROS; however, the consumption of whey and soy protein did not improve plasma antioxidant status in the current study. It is suggested that the antioxidant activity of whey protein depends on the concentration of cysteine, which is a precursor for glutathione biosynthesis, as whey protein has been shown to increase glutathione concentrations in glutathione-deficient groups [31, 32]. However, caloric intake can also play a role in antioxidant capacity in athletes; energy restriction increases glutathione status in trained athletes and whey protein supplementation is not able to modulate this response [33]. Interestingly, soy protein supplementation decreased GSH in the present study indicating reduced antioxidant activity. In contrast, soy isoflavones were shown to increase the activities of antioxidant enzymes in humans [34], however the form of isoflavone administered played a role in the enhancement of antioxidant status. In fact, free soy isoflavones were shown to be more effective at increasing antioxidant status in rats when compared to protein-associated isoflavones and soy protein extracts [34].

In terms of body composition, neither whey nor soy protein supplementation was able to influence body fat, lean body mass, or markers of bone health in this study. Female endurance runners tend to have lower BMC than resistance exercisers [35] as young female endurance runners exhibit a suppressed bone mineral accrual pattern and therefore may be at risk for inadequate bone mass gains and low peak BMD [36]. Furthermore, low peak BMD is associated with an increased risk of bone fractures [37]. As a milk byproduct, whey protein contains the necessary components needed for bone formation and milk protein supplementation is reported to increase BMD via the suppression of osteoclast activity [38]. However, whey protein supplementation did not significantly affect BMC or BMD in this study. Further, while some research has shown that intact high-quality proteins such as whey and soy are efficiently utilized for the maintenance and net gain of skeletal muscle in response to training [39], there is not a strong body of evidence documenting that protein supplements improve body composition in athletes [1].

In conclusion, supplementation with whey protein decreased lipid peroxidation in in female endurance athletes suggesting a potential antioxidative action, while soy protein did not improve biomarkers of oxidative damage and inflammation.

\section{CONFLICT OF INTEREST}

The author(s) confirm that this article content has no conflicts of interest.

\section{ACKNOWLEDGEMENTS}

Supported by a grant from the Washington State Dairy Products Commission. The authors declare that they have no competing interests.

\section{PATIENTS CONSENT}

The Institutional Review Board of Washington Sate University approved all study procedures and all participants provided informed consent.

\section{REFERENCES}

[1] Rodriguez NR, DiMarco NM, Langley S. Joint position statement: nutrition and athletic performance. Med Sci Sports Exerc 2009; 41: 709-31.

[2] Froiland K, Koszewski W, Hingst J, Kopecky L. Nutritional supplement use among college athletes and their sources of information. Int J Sport Nutr Exerc Metabol 2004; 14: 104-20.

[3] Westerblad H, Bruton JD, Katz A. Skeletal muscle: energy metabolism, fiber types, fatigue and adaptability. Exp Cell Res 2010; 316: 3093-9

[4] Hill KM, Stathis CG, Grinfeld E, Hayes A, McAinch AJ. Coingestion of carbohydrate and whey protein isolates enhance PGC$1 \alpha$ mRNA expression: a randomised, single blind, cross over study. J Int Soc Sports Nutr 2013; 10: 8 .

[5] Ivy JL, Ding Z, Hwang H, Cialdella-Kam LC, Morrison PJ. Post exercise carbohydrate-protein supplementation: phosphorylation of muscle proteins involved in glycogen synthesis and protein translation. Amino Acids 2007; 35: 89-97.

[6] Tarnopolsky M. Protein requirements for endurance athletes. Nutrition 2004; 20: 662-8.

[7] Powers SK, Jackson MJ. Exercise-induced oxidative stress: cellular mechanisms and impact on muscle force production. Physiol Rev 2008; 88: 1243-76.

[8] Chew BP, Park JS. Carotenoid action on the immune response. J Nutr 2004; 134: S257-61.

[9] Neubauer O, Reichhold S, Nics L, et al. Antioxidant responses to an acute ultra-endurance exercise: impact on DNA stability and indications for an increased need for nutritive antioxidants in the early recovery phase. Br J Nutr 2010; 104: 1129-38.

[10] Ackland TR, Lohman TG, Sundgot-Borgen J, et al. Current status of body composition assessment in sport: review and position statement on behalf of the ad hoc research working group on body composition health and performance, under the auspices of the I.O.C. Medical Commission. Sports Med 2012; 42: 227-49.

[11] Myburgh KH, Bachrach LK, Lewis B, Kent K, Marcus R. Low bone mineral density at axial and appendicular sites in amenorrheic athletes. Med Sci Sports Exerc 1993; 25: 1197-202.

[12] Krall EA, Dawson-Hughes B. Heritable and life-style determinants of bone mineral density. J Bone Miner Res 1993; 8: 1-9.

[13] Crouter SE, DellaValle DM, Haas JD. Relationship between physical activity, physical performance, and iron status in adult women. Appl Physiol Nutr Metab 2012; 37: 697-705.

[14] Elia D, Stadler K, Horváth V, Jakus J. Effect of soy- and whey protein-isolate supplemented diet on the redox parameters of trained mice. Eur J Nutr 2006; 45: 259-66.

[15] Takada Y, Aoe S, Kumegawa M. Whey protein stimulates the proliferation and differentiation of osteoblastic MC3T3-E1 cells. Biochem Biophys Res Commun 1996; 223: 445-9.

[16] Andersen LL, Tufekovic G, Zebis MK, et al. The effect of resistance training combined with timed ingestion of protein on muscle fiber size and muscle strength. Metabolism 2005; 54: 1516.

[17] Ryan-Borchers TA, Park JS, Chew BP, McGuire MK, Fournier LR, Beerman KA. Soy isoflavones modulate immune function in healthy postmenopausal women. Am J Clin Nutr 2006; 83: 111825.

[18] Nikawa T, Ikemoto M, Sakai T, et al. Effects of a soy protein diet on exercise-induced muscle protein catabolism in rats. Nutrition 2002; 18: 490-5. 
[19] Wu J, Wang X, Chiba H, et al. Combined intervention of soy isoflavone and moderate exercise prevents body fat elevation and bone loss in ovariectomized mice. Metabolism 2004; 53: 942-8.

[20] Hartman JW, Tang JE, Wilkinson SB, et al. Consumption of fatfree fluid milk after resistance exercise promotes greater lean mass accretion than does consumption of soy or carbohydrate in young, novice, male weightlifters. Am J Clin Nutr 2007; 86: 373-81.

[21] Uchiyama M, Mihara M. Determination of malonaldehyde precursor in tissues by thiobarbituric acid test. Anal Biochem 1978; 86: 271-8.

[22] Margonis K, Fatouros IG, Jamurtas AZ, et al. Oxidative stress biomarkers responses to physical overtraining: implications for diagnosis. Free Radic Biol Med 2007; 43: 901-10.

[23] Maughan RJ. Nutritional status, metabolic responses to exercise and implications for performance. Biochem Soc Trans 2003; 31: 1267-9.

[24] Kerasioti E, Stagos D, Jamurtas A, et al. Anti-inflammatory effects of a special carbohydrate-whey protein cake after exhaustive cycling in humans. Food Chem Toxicol 2013; pii: 50278-6915 [Epub ahead of print].

[25] Hamad EM, Taha SH, Abou Dawood AG, Sitohy MZ, AbdelHamid M. Protective effect of whey proteins against nonalcoholic fatty liver in rats. Lipids Health Dis 2011; 10: 57-63.

[26] Sierens J, Hartley JA, Campbell MJ, Leathem AJC, Woodside JV. Effect of phytoestrogen and antioxidant supplementation on oxidative DNA damage assessed using the comet assay. Mutat Res 2001; 485: 169-76.

[27] Giles D, Wei H. Effect of structurally related flavones/isoflavones on hydrogen peroxide production and oxidative DNA damage in phorbol ester-stimulated HL-60 cells. Nutr Cancer 1997; 29: 77-82.

[28] Danesh J. C-reactive protein in healthy and in sick populations. Eur Heart J 2000; 21: 1564-5.

[29] Suzuki K, Nakaji S, Yamada M, Totsuka M, Sato K, Sugawara K. Systemic inflammatory response to exhaustive exercise. Cytokine kinetics. Exerc Immunol Rev 2002; 8: 6-48.
[30] Zaldivar F, Wang-Rodriguez J, Nemet D, et al. Constitutive proand anti-inflammatory cytokine and growth factor response to exercise in leukocytes. J Appl Physiol 2006; 100: 1124-33.

[31] Balbis E, Patriarca S, Furfaro AL, et al. Whey proteins influence hepatic glutathione after $\mathrm{CCl} 4$ intoxication. Toxicol Ind Health 2009; 25: 325-8.

[32] Micke P, Beeh KM, Schlaak JF, Buhl R. Oral supplementation with whey proteins increases plasma glutathione levels of HIV-infected patients. Eur J Clin Invest 2001; 31: 171-8.

[33] Rankin JW, Shute M, Heffron SP, Saker KE. Energy restriction but not protein source affects antioxidant capacity in athletes. Free Radic Biol Med 2006; 41: 1001-9.

[34] Barbosa AC, Lajolo FM, Genovese MI. Effect of free or proteinassociated soy isoflavones on the antioxidant status in rats. J Sci Food Agric 2011; 91: 721-31.

[35] Heinrich CH, Going SB, Pamenter RW, Perry CD, Boyden TW, Lohman TG. Bone mineral content of cyclically menstruating female resistance and endurance trained athletes. Med Sci Sports Exerc 1990; 22: 558-63.

[36] Barrack MT, Van Loan MD, Rauh MJ, Nichols JF. Physiologic and behavioral indicators of energy deficiency in female adolescent runners with elevated bone turnover. Am J Clin Nutr 2010; 92: 652-9.

[37] Burrows M, Nevill AM, Bird S, Simpson D. Physiological factors associated with low bone mineral density in female endurance runners. Br J Sports Med 2003; 37: 67-71.

[38] Uenishi K, Ishida H, Toba Y, Aoe S, Itabashi A, Takada Y. Milk basic protein increases bone mineral density and improves bone metabolism in healthy young women. Osteoporos Int 2007; 18: 385-90.

[39] Tipton KD, Elliott TA, Cree MG, Aarsland AA, Sanford AP, Wolfe RR. Stimulation of net muscle protein synthesis by whey protein ingestion before and after exercise. Am J Physiol Endocrinol Metab 2007; 292: 71-6.

(C) Tara et al.; Licensee Bentham Open

This is an open access article licensed under the terms of the Creative Commons Attribution Non-Commercial License (http://creativecommons.org/licenses/by-nc/3.0/) which permits unrestricted, non-commercial use, distribution and reproduction in any medium, provided the work is properly cited. 